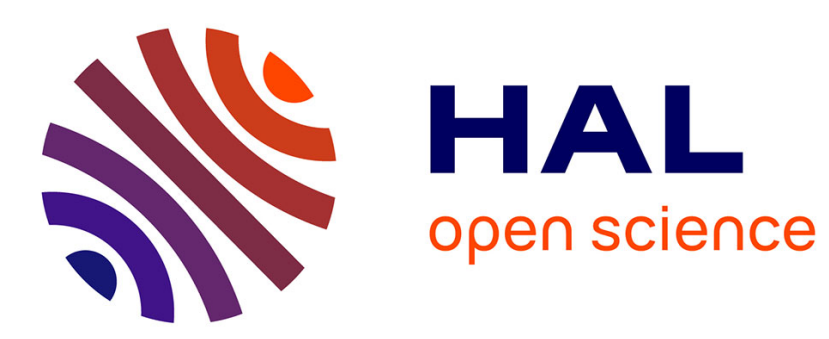

\title{
A FRACTOGRAPHIC STUDY OF ELECTRICAL PORCELAINS CONTAINING ALUMINA
}

\author{
E. Carlström, R. Carlsson
}

\section{To cite this version:}

E. Carlström, R. Carlsson. A FRACTOGRAPHIC STUDY OF ELECTRICAL PORCELAINS CONTAINING ALUMINA. Journal de Physique Colloques, 1986, 47 (C1), pp.C1-563-C1-567. 10.1051/jphyscol:1986185 . jpa-00225616

\section{HAL Id: jpa-00225616 https://hal.science/jpa-00225616}

Submitted on 1 Jan 1986

HAL is a multi-disciplinary open access archive for the deposit and dissemination of scientific research documents, whether they are published or not. The documents may come from teaching and research institutions in France or abroad, or from public or private research centers.
L'archive ouverte pluridisciplinaire HAL, est destinée au dépôt et à la diffusion de documents scientifiques de niveau recherche, publiés ou non, émanant des établissements d'enseignement et de recherche français ou étrangers, des laboratoires publics ou privés. 


\title{
A FRACTOGRAPHIC STUDY OF ELECTRICAL PORCELAINS CONTAINING ALUMINA
}

\author{
E. CARLSTRÖM and R. CARLSSON \\ Swedish Institute for Silicate Research, Box 5403, \\ S-402 29 Göteborg, Sweden
}

\begin{abstract}
Résumé - Des porcelaines électrotechniques ont été étudiées à l'aide d'examens fractographiques.Les défauts initiateurs de la rupture sont typiquement des grains de quartz pour une porcelaine extrudée à basse teneur en alumine et des pores pour une porcelaine pressée isostatique à haute teneur en alumine. La constante du miroir de rupture a été déterminée à $1.0 \mathrm{MN} / \mathrm{m}^{3} / 2$ et la valeur des contraintes résiduelles évaluée vers go MPa pour cette dernière.

Abstract - Electrical porcelains have been studied using fractographic methods. Typical strength controlling defects were quartz grains for an extruded low-alumina porcelain and pores for an isostatically pressed high-alumina porcelain. The fracture mirror constant was measured to $1.0 \mathrm{MN} / \mathrm{m}^{3 / 2}$ and the residual stress was estimated to approximately $90 \mathrm{MPa}$ for the isostatically pressed porcelain.
\end{abstract}

\section{I - INTRODUCTION}

Fractography is a well established method to characterize fracture surfaces of glasses as well as of high performance ceramics such as silicon nitride and silicon carbide /1,2/. The information about mode of failure and failure origin that can be obtained by fractography is of value, both for the designer of a ceramic component that has to bear a load, as well as for the material developer who wants to make stronger materials.

Fractography can also be applied to the traditional poly-crystalline ceramics even if the method is less used In this field $/ 3,4 /$.

Electrical porcelains for high voltage applications have to bear high tensile loads. Strength and slow crack growth are factors that affect the performance of such materials. In this paper the fracture of some electrical porcelains have been studied using fractographic methods.

\section{II - MATERIALS}

Four electrical porcelains (supplied by Ifö Electric AB, Sweden) were studied (table 1). The porcelains were alumina containing porcelains for high voltage insulators. Circular rods with a diameter of 15.4-16.3 mm were used as received, in the fracture tests. 


\section{III - EXPERIMENTAL METHODS}

The rods were fractured in three point bending using a range of cross-head speeds. The fracture surfaces were coated with gold and observed in the scanning electron microscope (SEM) as well as with a light optical microscope (LOM). Fracture origins were analyzed by energy dispersive X-ray analysis (EDX). Photographs were taken of the specimens and the sizes of the fracture features were measured.

Table 1 - Materials

\begin{tabular}{|c|l|c|}
\hline Porcelain & Forming method & Alumina content (w/o) within the range \\
\hline B & extrusion & $35-40$ \\
C & $\begin{array}{l}\text { extrusion } \\
\text { isostatic pressing } \\
\text { D }\end{array}$ & $\begin{array}{l}\text { isostatic pressing and } \\
\text { green machining. }\end{array}$ \\
\hline
\end{tabular}

\section{IV - RESULTS}

The characteristic features of a brittle fracture could be observed, such as fracture mirror, mist, hackle (figure 1) and on the stronger samples macroscopic crack-branching.

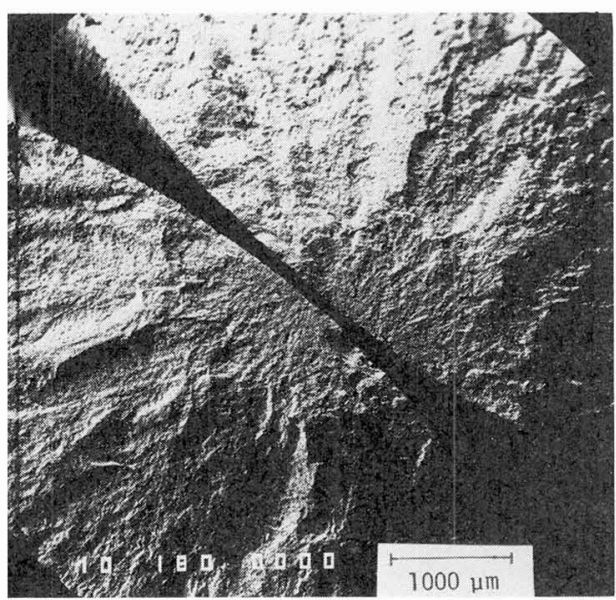

Fig. 1 - Fracture mirror with hackle lines on porcelain $B$.

A theoretical defect size for a penny shaped sirface crack was calculated using the equation below. 


$$
\begin{aligned}
& \mathrm{K}_{I c}=Y \sigma \mathrm{a}^{1 / 2} \\
& \mathrm{Y}=\text { geometric factor } \\
& \sigma=\text { fracture stress } \\
& a=\text { defect size }
\end{aligned}
$$

$K_{I c}$ was measured with the controlled surface flaw technique /5/.

The theoretical defect size was compared to what could be measured on the fracture surface (table 2). In an ideal case, these should show good agreement and indicate if the actual fracture origin was observed $/ 6 /$.

Table 2 - Types and sizes of fracture origins

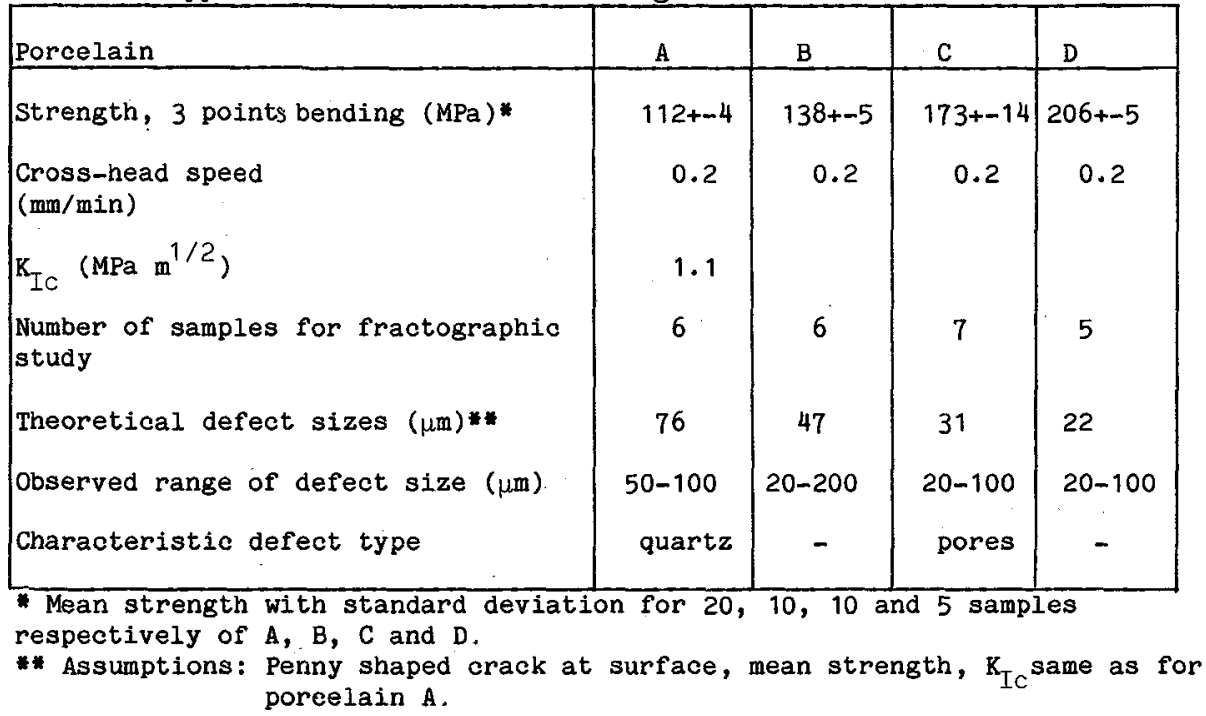

In porcelain A quartz grains are the typical failure origins (figure 2). Cracks can often be observed around the quartz grains. These cracks are 1ikely to be caused by the volume change accompanying the quartz transformation. A portion of the quartz is substituted by alumina in porcelain $B$. In this porcelain quartz grains at fracture origins still exist but other types of defects such as agglomerates /7/ can also be found. In porcelain $C$ the typical defects are pores. These pores probably originate from inter- or intraagglomerate voids in the green body formed during isostatic pressing. In porcelain D no typical defect type could be found.

The radius of the fracture mirror (mist/hackle radius) was measured on porcelain D. This porcelain had the highest mean strength of the four porcelains and the most pronounced fracture mirrors. The mirror radius is related to the fracture strength by

$$
\sigma r^{1 / 2}=A
$$

where $r$ is the mirror radius and $A$ the fracture mirror constant for the particular material studied. In a porcelain material we have internal stresses from 


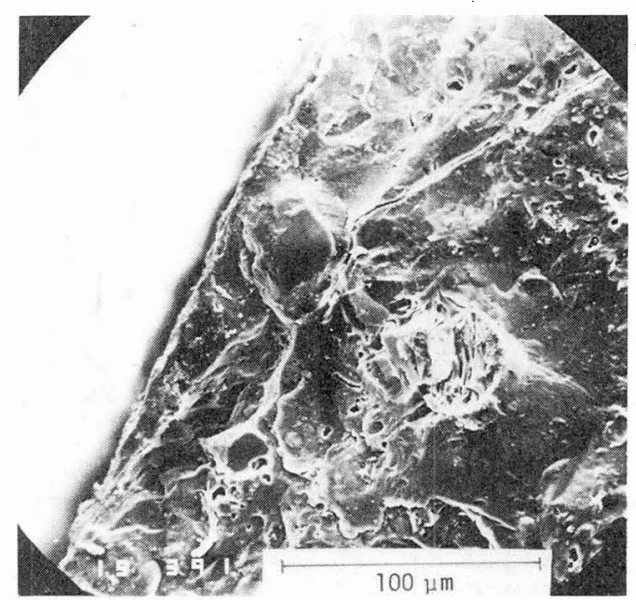

Fig. 2 - Fracture on porcelain A. A quartz grain can be seen in the middle of the micro-graph.

thermal expansion anisotropy and phase transformations. These were estimated by plotting fracture stress as a function of $r^{-1 / 2}$ as suggested by Mecholsky $/ 6 /$. Equation (2) can be written as below to account for the internal stresses.

$$
\begin{aligned}
& \left(\sigma_{a}+\sigma_{r}\right) r^{1 / 2}=A \\
& \sigma_{a}=\text { applied stress } \\
& \sigma_{r}^{a}=\text { residual stress }
\end{aligned}
$$

The residual stress was estimated to $94 \mathrm{MPa}$ and the fracture mirror constant (hackle/mist) to $1.0 \mathrm{MN} / \mathrm{m} 3 / 2$. Theoretical calculations of schuller and Stärk /8/ have given similar values of the residual stress in alumina porcelains.

\section{$V-$ DISCUSSION}

Fractographic methods have been found useful to identify strength controlling defects in electrical porcelains.

The actual. sizes of some of the encountered flaws such as agglomerates and quartz grains are difficult to measure because of their associated cracks. The strength controlling crack is the one in the same plane as the fracture mirror. The defect sizes reported in this investigation are the quartz grains and agglomerates sizes and not their associated crack sizes. This together with residual stresses in the material can account for the differences between observed and calculated defects.

The method for estimating the residual stresses has not been widely tested yet so allowance must be made for possible imprecision of that result.

\section{ACKNOWLEDGEMENT}

The authors wish to thank Lars Eklund for the SEM work and Rolf Ahlgren, Ifö Electric $A B$ for supplying the test bars. 


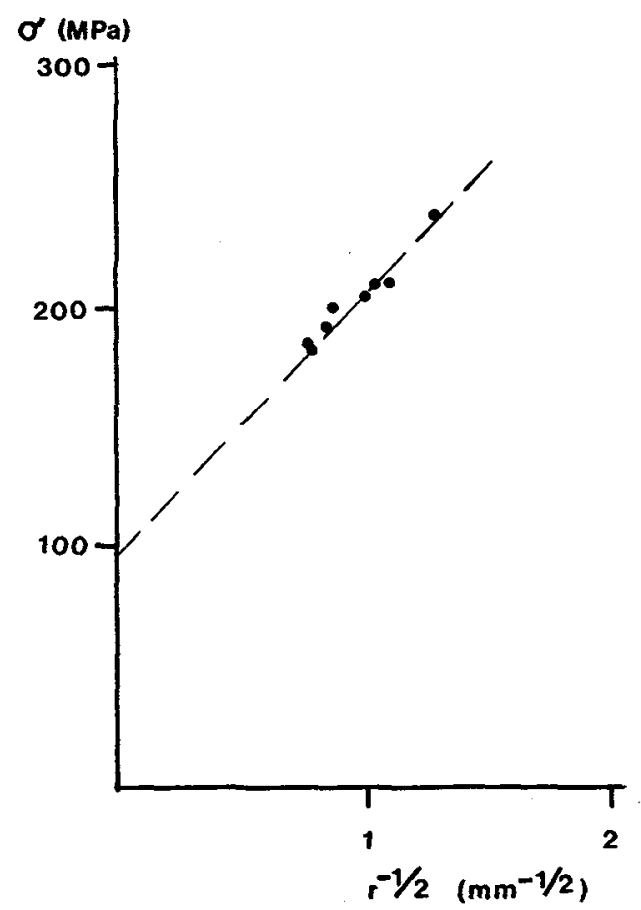

Fig. 3 - Fracture stress of porcelain D plotted as a function of $\mathrm{r}^{-1 / 2}$. The slope of the line is the fracture mirror constant and the intercept indicates the residual stress of the material.

\section{REFERENCES}

/1/ Rice, R.W., in Fracture Mechanics of Ceramics 1, ed. Bradt, Hasṣelman and Lange, (1973) 323, Plenum Press, New York.

/2/ Rice, R.W., in Surfaces and Interfaces of Glass and Ceramics, ed. Frechette, La Course and Burdish (1974) 439, Plenum Press, New York.

/3/ Dannheim H. and Del H.J., cfi/Ber DKG 61 (1984) 84.

14/ Dannheim H., Ber DKG 56 (1979) 323.

15/ Carlström E., Carlsson R., Tjernlund A.K. and Johannesson B., in Fracture Mechanics of Ceramics 7-8, ed. Bradt, Evans, Hasselman and Lange (to be published).

16/ Mecholsky J.J. and Freiman S.W., ASTM STP 678, ed. Freiman (1979) 136.

/7/ Lange F.F. and Metcalf M., J Am Ceram Soc 66 (1983) 398.

18/ Schuller K.H. and Stärk K., Ber. DKG 44 (1967) 458 